\title{
PERCEIVED EFFECT OF SOCIAL MEDIA MARKETING ON MALAYSIAN FILM AUDIENCE
}

\author{
Puteri Sarah Hanim Mohamad Shaiful, Shazleen Mohamed and Suhaimee Saahar \\ Faculty of Communication \& Media Studies, Universiti Teknologi MARA, Shah Alam, Malaysia
}

\begin{abstract}
For this study we have adopted a comparative approach to better understand Perceived Effect of Social Media Marketing on Malaysian Film Audience including its successes in regards to popular social tactics and campaigns as well as where it may fall short within the realm of marketing as a whole and to explore the differences marketing strategies. The study also found the benefits and challenges using the strategies and takes a look into how social media can best be used and implemented to create for a successful marketing campaign for the theatrical release of a film in Hollywood to implied on film industry in Malaysia. This study uses Qualitative method which utilizes the Focus- Group interview, throughout this study, netizen's comments and discussions on social media are analysed to also determine how the social media marketing may influence the audience
\end{abstract}

Keywords: Social Media Marketing, Audience Preference

\section{Introduction}

With the rise of social media, there are new strategies and tactics that marketers and advertisers must take advantage of when creating a campaign. Social media platforms are a place for targeted tailoring and personalization. Social media is exactly what it is by definition: social. Personally connecting with social audiences through a marketing or advertising campaign is the best way to find success with that campaign By investigating current social trends and best practices regarding social media marketing campaigns performed by several major film studios in the Malaysia and Hollywood, it will benefit social media, marketing, advertising and film industry professionals who are looking to increase their visibility and create a more successful campaign on social media.

\section{Problem statement}

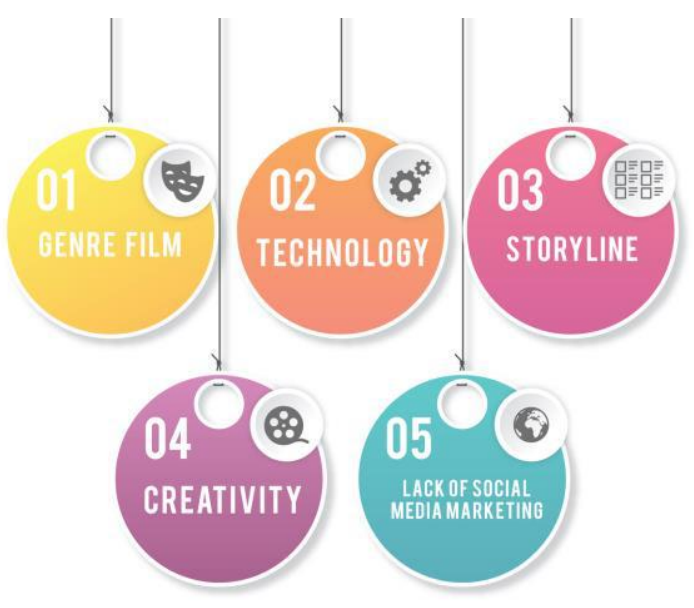

Corresponding Author E-mail: * puterisarahhanim@gmail.com 
Marketing is an essential part of a movie's success in theatres. Without proper marketing development, a movie with fantastic plotlines, characters, actors, sets, and special effects may fail to attract an audience. This study focuses on the effectiveness of Social Media Marketing on Malaysian Film Audience. In the last few years, the rise of social media as a personal form of expression has exploded. Most of the time, However, companies don't take advantage of the fact that mostly all of their consumers are on social media. To traditional marketers, social media is still a relatively new and unexplored terrain and that can be intimidating. However, "today, many analysts agree that social communities should be a top priority for marketers.

A great marketing strategy guarantees a good opening end of the week for the film. Additional social media for movie marketing activities are conceivable if the star of the film is included like radio challenge, specials, reconciliation, and online chat. There are not very many filmmakers and studios that comprehend the advanced medium well yet most concur that the medium should be utilized legitimately.

\section{Research objectives}

- To identify the marketing tools used in promoting the film in Malaysia.

- To understand and to explore the effect of audience perception toward film promotion

\section{Research questions}

- What kinds of social media marketing tools are usually used?

- What is the effect of audience perceptions towards social media marketing in Malaysia?

\section{Conceptual framework}

This theory explains that the objectives of social media marketing include boosting sales and brand awareness, refining brand image, stimulating consumers' visits to online platforms, addressing concerns regarding marketing costs as well as establishing user interactivity on social media by encouraging them to generate content by either posting or sharing anything deemed suitable for the purpose of social media marketing on the various social media platforms (Ashley and Tuten, 2015; Bianchi and Andrews, 2015; Schultz and Peltier, 2013; Bernoff and Li, 2008).

Social media marketing is made possible via the availability of the Internet and interactive technologies. Due to its accessibility, effectiveness in reaching a wide set of audiences as well as its benefits for branding, social media marketing is employed by numerous organisations and firms (Michaelidou, Siamagka, \& Christodoulides, 2011). As indicated by Andersson (2017), through social media marketing, firms can establish relationships with consumers, staff, communities and even stakeholders, to name a few. As such, due to the objectives and characteristics of the social media marketing theory, it can be said that the theory forms the basis of this study as it justifies the role of social media as a platform to promote breastfeeding via social media campaigns. Social media marketing is part of the efforts to promote breastfeeding to first-time mothers because it enables breastfeeding advocacy campaigns to reach their targeted audience on a larger, cost-effective scale. 


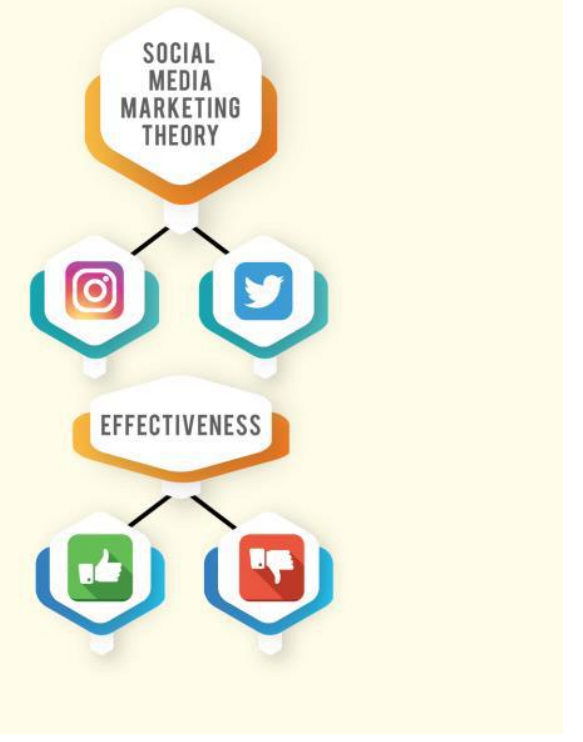

Figure 1: Conceptual Framework

\section{Literature review}

\section{Social Media Marketing}

Social media can be used in many different ways within a single marketing campaign that is what makes it the most versatile platform to structure a campaign on. Social media platforms are becoming bigger and better for advertising not only because of the extreme reach potential, but also because social sites "gather all sorts of data on each user's age, consumption patterns, interests and so on" (Economist, 2015,).

Regardless of when social media marketing is established during the campaign, using this form of nontraditional advertising allows a company to develop and actively communicate with customers, increase brand awareness and brand equity, and do it all for a lower cost than traditional methods (Elliot, 2011).

\section{Effectiveness Social Media Marketing on Audience}

Effective marketing means being able to communicate the strengths of the movie to an audience who would appreciate those strengths. As younger audiences continue to spend significant amounts of time on the Internet, marketers are trying to reach those people in ways that reliably drives ticket sales. Though it would seem as if incorporating social media into movie marketing campaigns would be an effective means of reaching these younger audiences

There are many factors that influence a movie's box office success. Effective marketing means being able to communicate the strengths of the movie to an audience who would appreciate those strengths. As younger audiences continue to spend significant amounts of time on the Internet, marketers are trying to reach those people in ways that reliably drives ticket sales. Though it would seem as if incorporating social media into movie marketing campaigns would be an effective means of reaching these younger audiences 


\section{Twitter}

Twitter is different kinds of social networking informal communication locales that have same character and impacts on the utilization of Twitter as it works in associating the other individuals from alternate spots to alternate places in a speed of time. The utilization of Twitter would furnish its clients to remain refreshed with the ongoing updates with the majority of the Twitter clients that share their sentiment or words through the Twitter.

Twitter is being found as the microblogging where individuals ready to retweet their tweets with numbers of users that utilization Twitter as one of their medium or divert in correspondence and conveying their data that they needed to share on (Kwak, H., Lee, C., Park, H. also, Moon, S., 2010). highlighted that, Twitter gives a viable method for correspondence in impacting the other user's which the clients who tailed somebody on the Twitter would going to as it would ready to make alternate clients to be affected with the words that has been "tweeted" among them, which they would likely going to trust the posted things in the profile.

\section{Instagram}

Instagram can be viewed as both the first and last level of interaction with a movie picture: from a customer initially seeing a post in pre-production, to following the channel and providing a community for fans after the movie's release. Movies have additionally had the capacity to take advantage of the adolescent and picturebased intensity of Instagram. Since its dispatch, Instagram has given us an astounding stage to interface with our fans and recount our story outwardly. Besides, presently Instagram have new highlights which is IGTV. IGTV will be a noteworthy player declared and propelled in June, IGTV is the new video organize committed exclusively to portable clients. Not in any way like YouTube and other video spilling stages, is IGTV committed to vertical video playback and, along these lines, sensible for advertisers and substance producers that are watching out for a convenient crowd

\section{Social Media Marketing Theory}

This theory explains that the objectives of social media marketing include boosting sales and brand awareness, refining brand image, stimulating consumers' visits to online platforms, addressing concerns regarding marketing costs as well as establishing user interactivity on social media by encouraging them to generate content by either posting or sharing anything deemed suitable for the purpose of social media marketing on the various social media platforms (Ashley and Tuten, 2015; Bianchi and Andrews, 2015; Schultz and Peltier, 2013; Bernoff and Li, 2008).

Social media marketing is made possible via the availability of the Internet and interactive technologies. Due to its accessibility, effectiveness in reaching a wide set of audiences as well as its benefits for branding, social media marketing is employed by numerous organisations and firms (Michaelidou, Siamagka, \& Christodoulides, 2011).

\section{Methodology}

The study is a methodological inquiry into the interpretation of qualitative data. It explores a grounded theory approach to the synthesis of data, examining, in particular, the identification and building of categories, as one part of the coding, categorizing, and thematic development sequence and it focuses on ways of organizing data and attaching meaning, as research problems embedded in cultural context are explored.

\section{Instrument}

In an attempt to understand the successful promotion strategies from the audience's point of view, group observations and interviews were conducted in the area Klang Valley aged between 20-35 years old. Focus 
group is used as a tool to collect primary data for this study. Small groups are often used "to reveal consumer needs, motives, perceptions and attitudes". Small group consists of 6 respondents with equal proportion of males and females. The focus group took approximately 60 minutes. All respondents are are movie lovers and highly involved in movie watching. Respondents hailed from a range of different states of the country and cultural backgrounds

\section{Focus Group}

Focus Group is a type of in-depth interview accomplished in a group, whose meetings present characteristics defined with respect to the proposal, size, composition, and interview procedures. The focus or object of analysis is the interaction inside the group. The participants influence each other through their answers to the ideas and contributions during the discussion. The moderator stimulates discussion with comments or subjects. The fundamental data produced by this technique are the transcripts of the group discussions and the moderator's reflections and annotations.

\section{Data Gathering and Data Analysis}

According to the Braun and Clarke (2006), thematic analysis was the qualitative study that emphasize on existing and actions with the classifiable subjects in order to recognize, examine and report the information. Besides systematizing the information in generous way, the researcher had to be conversant with prerequisite of the segments which involved the information, produce the preliminary code, point for the subjects, study the research topic as well describe the research studied before generating the report.

\section{Findings}

\section{Social Media Marketing used in Film Promotion}

Film marketing in Hollywood are more updated to compare with Malaysia. It's important to keep the ball rolling with your marketing, starting to spread the word and build interest in your project early will ultimately pay off by getting audiences to see your film. It is especially if you're focusing on a how-to promoting your film, it's crucial that you and make contact not only with fans but with taste-makers and decision-makers. They want to hear about the making of it, the ups, the downs, the bloopers, behind the scenes, the funny bits and giving more of an insight into film processes will help the audience become more emotionally invested in the film.

\section{Effectiveness of Social Media Marketing on Malaysian Film Audience}

A film can be used as one of the most prominent media for storytelling (Fuchs, A., 2012) and is used in many studies to explore human behaviour. Film as a channel and scientific device, documents and exposes phenomena (Kracauer, 1960), not only because it enables the analysis of a large scope of time occurrences, it can also record reality. The researcher's finding could relate to this A look at some of the biggest hits at the box office this year proves that many of the most successful films also had strong social media campaigns. the most popular social media platforms include Facebook, Twitter, and Instagram. Things become viral on the internet for many different reasons. Whether it be a fun or a hilarious meme that people can relate to. All of these social media platforms are being used in different ways for fans to interact with and learn more about the characters and the movie, while at the same time Connect with social media influencers

\section{Conclusion}

The purpose of this study was to analyses social media marketing and how it affected the relationship between the audience and film promoting. Since most people use social media as a means of communicating, utilizing it can help develop relationships between audience and film promoting. Social media consists of distributing 
content that will give the audiences a chance to gain an in-depth look at different aspects of the movie. This can include photos and videos, articles, or behind-the-scenes content in a film promoting.

Most participants said that they were most likely to learn about movies through social media, which gave evidence that this medium does have an impact on moviegoers. In these channels, people were mostly looking for videos, pictures, or behind the scenes content. Other suggested content included reviews, trailers, and information about the actors of the movie. This suggests that people would be interested in visiting these profiles if they had more diverse content in addition to what they already supply.

Doubtlessly, 'social media' has a very important role to become a small village of the world. Social media while eliminating walls and distances, it was closed people in many ways. A major turning point in the history of the world that the impact of the internet and social media being felt more and more every day of our economic, political and socio-cultural lives. This power affecting all aspects of human life has been integrated into the film industry. Today the film companies see that social media and internet are one of the indispensable elements competitive powers. Users are now not passive watcher in this environment; they have started to become active players. Consumers with have written blogs, their Tweets and sharing on Instagram, social media with product evaluations has been the scene of the birth of creative consumers and content created by consumers.

\section{References}

Rosnan, H., Ismail, M. N., \& Mohd Daud, N. (2010). The globalization of film business and its effect on the Malaysian film industry. pp. 325-332.

Successful Film Digital Marketing. (21 February, 2017). Retrieved from EETTI: http://eetti.com/blog/2017/02/21/successful-film-marketing-strategies-film-promotion/

Bajpai, V., Pandey, S. and Shriwas, S. 1. (2012). Social media marketing: Strategies and its impact. International Journal of Social Science and Interdisciplinary Research, 1 (7) .

Berg, B. (2001). Qualitative Research Methods for the Social Sciences. 4th Edition. Boston, MA: Ally \& Bacon.

Blandford, S., Grant, B. K., \& Hillier, J. (2001). The film studies dictionary. New York: Oxford University Press.

Boyce, C. and Neale, P. (2006). Conducting in-depth interviews: a guide for designing and conducting in-depth interviews for evaluation input. USA Pathfinder.

Braun, V. \&. (2006). Using thematic analysis in psychology. Qualitative Research In Psychology, 3 (2). 77-101.

Clara Pafort-Overduin, John Sedgwick, Lies Van de Vijver. (2018). Identifying Cinema Cultures and Audience.

Creswell, J.W., Clark, V.L.P., Guttmann, M.LM \& Hanson W.E. (2003). Advanced Mixed Methods Research Design. Handbook of Mixed Methods in Social and Behavioral Research. Thousand Oaks CA Sage.

Dance, S. (2010). Can Twitter save the day?

Daud, N. M. (2010). The globalization of film business and its effect on the Malaysian film industry.

Denzin, N.K., \& Lincoln, Y.S. (2005). Introduction: The discipline and practice of qualitativeresearch. In N.K. Denzin \& Y.S. Lincoln (Eds.), . The sage handbook of qualitative research (2nd ed.). Thousand Oaks, CA: Sage.

Doody, O., \& Noonan, M. (2013). Preparing and conducting interviews to collect data.Nurse Researcher. , 20(5), 28-32. .

Durie, J. (. (1993). The Film Marketing strategies for independent films. London: MEDIA Business School, Madrid.

Economist, T. (29 August , 2015,). Retrieved from Marketing in the Digital Age: A Brand New Game: http://www.economist.com/news/business/21662543-people-spend-more-time-social-media-advertisers-arefollowing-them-brand-new-game

Evans.D ; Susan Bratton. (2012). Social Media Marketing: An Hour a Da 2nd Edition. SYBEX.

Farb, Brittany. (2011 September). Why Old-School Advertising Delivers the Wrong. Retrieved from https://www.questia.com/magazine/1G1-266943292/why-old-school-advertising-delivers-the-wrong-message 
Gibson, W. (2009). Negotiating textual talk: conversation analysis, pedagogy and the organisation of online asynchronous discourse. British Educational Research Journal 35 (5), 705-721.

Harvey, C. G., Stewart, D. B., \& Ewing, M. T. . (2011). Forward and delete: What drives peerto-peer message propagation across social networks? Journal of Consumer Behaviour, 365-372.

Hoskins, C. a. (1991). The US competitive advantage in the global television market: is it sustainable in the new broadcasting environment? Canadian Journal of Communication, Vol. 16, 207-24.

Ibid. (2017 May, 2017). Film Marketing Strategies: From Social Media to Persona Marketing. Retrieved from Next Big What: https://www.nextbigwhat.com/film-marketing-strategies-297/

Kunczik, M., Zipfel, A. . (2006). On the use of the mass media for important things.

Kvale, S. (2007). Doing Interview. Thousand Oaks, CA Sage.

Kwak, H., Lee, C., Park, H. and Moon, S. (2010). What Is Twitter, a Social Network or a News Media?

Lynda. (18 July, 2017). 5 Steps to Successful marketing. Retrieved from Stage32.com: https://medium.com/@Stage32online/5-steps-to-a-successful-film-marketing-campaign-3983dd06898c

McQuail, D. (2005). McQuail's Mass Communication Theory. 5th Edition. London: Sage Publication Ltd.

Merriam, S. (2002). Qualitative Research in Practice: Examples for Discussion and Analysis. 1st Edition. San Fransico.

Mohd Nazari Ismail. (2010). The globalization of film business and its effect on the Malaysian film industry.

Nigam, A. (2012). Viral Marketing on Brand Equity Building With Reference To Online Social Networking Sites. Influence of Viral Marketing on Brand Equity Building With Reference To Online Social Networking Sites.

Palmgreen, P. \& Rayburn, J. D. (1979). Uses and gratifications and exposure to public television: A discrepancy approach. Communication Research, 6, 155-180.

Polit, D.F., Beck, C.T. and Hunger, B.P. (2001). Essentials of Nursing Research: Methods, Appraisal and Utilization. 5th Ed. Philadelphia.

Quan-Haase, A. \& Young, A. . (2010). Uses and gratifications of social media: A comparison ofFacebook and instant messaging. Bulletin of Science, Technology \& Society. 30(5), 350 -.

Ramanauskienè, J. (2008). Marketing Strategies.

Ruggiero, T. (2000). Uses and gratification theory in the 21st century. Mass Communication \& Society. 3(1), 337. .

Salwen, Michael B. and Stacks. (1996). "Uses and Gratifications." An Integrated Approach to Communication Theory and Research.

Teijlingen, V.E., Rennie, A.M., Hundley, V. \& Graham, W. (2001). The importance of Conducting and Reporting Pilot Studies: The Example of The Scottish Births Survey. Journal of Advance Nursing, 34, 289-295.

Thirushen, N. (2011). The effectiveness of advertising through the social media in Gauteng, NorthWest University.

Tuten, T. (2008). Advertising 2.0: Social media marketing in a web 2.0 world.

Wang, Q., Fink, E., \& Cai, D. (2008). Loneliness, gender, and parasocial interaction: A uses andgratifications approach. Communication Quarterly. 56(1), 87-109. .

Wimmer, R.D. \& Dominick, J.R. (2011). Mass Media Research : An Introduction 9th editon. USA;

Zhang, S. (2016). Social Media Marketing Strategies in Commercial Movies. 